\title{
Symphyonema bifilamentata sp. nov., the Right Fischerella ambigua 108b: Half a Decade of Research on Taxonomy and Bioactive Compounds in New Light
}

\author{
Patrick Jung 1,*(D), Paul M. D'Agostino ${ }^{2}{ }^{(D)}$, Burkhard Büdel ${ }^{3}$ and Michael Lakatos $^{1}(\mathbb{D}$ \\ 1 Applied Logistics and Polymer Sciences, University of Applied Sciences Kaiserslautern, Carl-Schurz-Str. \\ 10-16, 66953 Pirmasens, Germany; Michael.lakatos@hs-kl.de \\ 2 Faculty of Chemistry and Food Chemistry, Technical University of Dresden, Chair of Technical Biochemistry, \\ Bergstraße 66, 01069 Dresden, Germany; paul.dagostino@tu-dresden.de \\ 3 Biology Institute, University of Kaiserslautern, Erwin-Schrödinger Str. 52, 67663 Kaiserslautern, Germany; \\ buedel@bio.uni-kl.de \\ * Correspondence: patrick_jung90@web.de
}

check for updates

Citation: Jung, P.; D'Agostino, P.M.; Büdel, B.; Lakatos, M. Symphyonema bifilamentata sp. nov., the Right Fischerella ambigua 108b: Half a

Decade of Research on Taxonomy and Bioactive Compounds in New Light. Microorganisms 2021, 9, 745 .

https://doi.org/10.3390/

microorganisms 9040745

Academic Editor: Assaf Sukenik

Received: 3 March 2021

Accepted: 31 March 2021

Published: 2 April 2021

Publisher's Note: MDPI stays neutral with regard to jurisdictional claims in published maps and institutional affiliations.

Copyright: (c) 2021 by the authors. Licensee MDPI, Basel, Switzerland. This article is an open access article distributed under the terms and conditions of the Creative Commons Attribution (CC BY) license (https:/ / creativecommons.org/licenses/by/ $4.0 /)$.

\begin{abstract}
Since 1965 a cyanobacterial strain termed 'Fischerella ambigua 108b' was the object of several studies investigating its potential as a resource for new bioactive compounds in several European institutes. Over decades these investigations uncovered several unique small molecules and their respective biosynthetic pathways, including the polychlorinated triphenyls of the ambigol family and the tjipanazoles. However, the true taxonomic character of the producing strain remained concealed until now. Applying a polyphasic approach considering the phylogenetic position based on the 16S rRNA and the protein coding gene $r b c L X$, secondary structures and morphological features, we present the strain 'Fischerella ambigua 108b' as Symphyonema bifilamentata sp. nov. 97.28. Although there is the type species (holotype) S. sinense C.-C. Jao 1944 there is no authentic living strain or material for genetic analyses for the genus Symphyonema available. Thus we suggest and provide an epitypification of S. bifilamentata sp. nov. 97.28 as a valid reference for the genus Symphyonema. Its affiliation to the family Symphyonemataceae sheds not only new light on this rare taxon but also on the classes of bioactive metabolites of these heterocytous and true-branching cyanobacteria which we report here. We show conclusively that the literature on the isolation of bioactive products from this organism provides further support for a clear distinction between the secondary metabolism of Symphyonema bifilamentata sp. nov. 97.28 compared to related and other taxa, pointing to the assignment of this organism into a separate genus.
\end{abstract}

Keywords: Symphyonema; true-branching; heterocytes; ambigol; polyphasic approach; Fischerella

\section{Introduction}

True-branching heterocytous cyanobacteria were formerly classified as Stigonematales [1], but various phylogenetic analyses have shown that the Nostocales form a monophyletic lineage within which the true-branching genera are scattered in several unrelated families, making Stigonematales polyphyletic [2,3] and thus an outdated taxon distinction. True-branching Nostocalean genera have the most complex morphological traits across the whole phylum Cyanobacteria, including various cell types, branching patterns, and thalli structures. Besides heterocytes (nitrogen fixation site) as the most distinctive cell type of all Nostocacean taxa, they can have akinetes (dormant resting cells), hormogonia (motile propagules), and necridia (controlled cell-death). Within the Nostocacean genera exhibiting false- or scytonematoid-branching pattern (e.g., Scytonema, Brasilonema), true-branching patterns of T-type (e.g., Westiellopsis, Fischerella), or Y-type (e.g., Mastigocladopsis, Symphyonemopsis) are included that can lead to a differentiated morphology of a basal section and significantly different lateral branches as commonly found in Stigonema, for example [2]. 
Although this wealth of striking morphological differences and characteristics that one might set into phylogenetic relations exists, it has been shown that true-branching cyanobacteria are polyphyletic based on genetics [2], and more recently based on heterocyte glycolipids [4]. According to the current taxonomic classification of cyanobacteria established by Komárek et al. in 2014 [3], the true-branched taxa are placed in the five families Symphyonemataceae (13 genera), Hapalosiphonaceae (28 genera), Stigonemataceae (5 genera), Capsosiraceae (4 genera) and Chlorogloeopsidaceae (1 genus). This makes a total of 51 genera of which only 11 (Westiella, Spelaeonaias, Iphinoe, Loriellopsis, Chlorogloeopsis, Aetokthonos, Mastigocladus, Mastigocoleus, Westiellopsis, Neowestiellopsis, Reptodigitus) are supported by molecular data such as the $16 \mathrm{~S}$ rRNA and only a few of them comprising the holotype species.

Resolving the taxonomy of true-branching cyanobacteria is complicated by the fact that only a few of these rare true-branching species have been deposited at public culture collections preventing a compiled resolution of their taxonomy in the context of novel, future isolates. In addition, most of them occur at extreme and thus less frequently sampled habitats such as thermal springs e.g., Fischerella thermalis [5], Chlorogloeopsis sp. [6], Mastigocladus laminosus [7], or caves e.g., Spelaeonaias floccida [8], Geitleria calcarea [9], Symphyonema cavernicolum [10]. In the case of the genus Symphyonema, a few species are described such as the aforementioned S. cavernicolum [10], S. kabooruum from the littoral zone of an acidic, coastal oligotrophic lake in Australia [11], the type species of the genus S. sinense [12] from wet, calcareous rocks of China and S. sinense var. minor from French Guiana [13] but without any of them being deposited at culture collections or available genetic information. The current genetic reference point for the whole genus are two $16 \mathrm{~S}$ rRNA sequences of isolates from soil in Papua New Guinea that were not taxonomically defined but support the distinct phylogenetic position of this genus based on the 16S rRNA [2].

However, one of the true-branching strains that gained the attention of several researchers of various disciplines during the past is 'Fischerella ambigua 108b' (Hapalosiphonaceae)that was isolated in 1965 from wet soil in Switzerland. From that point forward, 'Fischerella ambigua 108b' was the subject of various studies on bioactive cyanobacterial products without confirmation of its taxonomic assignment. Between 1965 and 2020 several studies were conducted that led, among other things, to the discovery of the polychlorinated triphenyls ambigol A-E [14-16] and their biosynthetic pathway [17], and the isolation of the tjipanazoles and characterization of their biosynthesis [18]. These and other findings were always discussed in light of bioactive compounds and their metabolic pathways extracted from related species, such as F. thermalis or F. muscicola, or related genera, including Westiellopsis, Hapalosiphon or Nostochopsis.

Here, we show that the strain 'Fischerella ambigua 108b', an important strain of many articles on drug discovery, in fact is a novel Symphyonema species based on a polyphasic approach. Using a combination of morphological information combined with the evaluation of its taxonomic position based on the 16S rRNA, 16S-23S ITS gene region, and the protein coding gene region $r b c L X$ allowed the establishment of Symphyonema bifilamentata sp. nov. As there is no culture material or genetic information of any other Symphyonema species available, we suggest that $S$. bifilamentata sp. nov. should act as reference point for the genus along with an epitypification and emendation of the genus Symphyonema provided here. The holotype of the genus Symphyonema is S. sinense C.-C. Jao but refers to two plates in the original publication only [12]. However, there is no designated type material in the form of a preserved specimen or a type culture available. According to the discussion in [19], we believe that this justifies an epitypification and suggests the new species described here as a new type specimen for the genus. To account in the traceable history of science for this specific strain, we included a revision on its natural products discussed in the new light of its taxonomic position, which removes it from Hapalosiphonaceae and places it into the distantly related Symphyonemataceae. 


\section{Materials and Methods}

\subsection{Origin of Strain}

Two identical cyanobacterial strains were isolated in 1965 from a shallow soil deepening that was wet at intervals at Mellingen, Switzerland, from Alfons Zehnder. Afterwards, both were given to the Swiss Federal Institute of Aquatic Science and Technology (EAWAG) culture collection (Dübendorf, Switzerland) as Fischerella ambigua 108a and 108b until they were transferred to the culture collection of Burkhard Büdel (University of Kaiserslautern, Department Plant Ecology and Systematics, Kaiserslautern, Germany) as strains 97.28a and $97.28 \mathrm{~b}$. In addition, strain $108 \mathrm{~b}$ was also given to the Culture Collection of Algae and Protozoa (CCAP; Scotland) as strain 1427/4 in 2004. According to information from all culture collections the strains were cultured in liquid nutrient deficient standard medium for cyanobacteria $\mathrm{BG} 11$ and $\mathrm{BG} 11_{0}$ (without nitrogen) medium at $17{ }^{\circ} \mathrm{C}$, at photosynthetic photon flux density of $30 \mu \mathrm{mol} \mathrm{m} \mathrm{m}^{-2} \mathrm{~s}^{-1}$ and a light:dark cycle of 18:6 h, which were also the conditions during our investigations.

\subsection{Morphological Characterization}

The morphology of the cyanobacterial isolate was checked weekly over the course of several months by light microscopy using a Panthera KU Trinocular (Motic) equipped with $10 \times, 20 \times, 40 \times$ and $100 \times$ magnification and oil immersion coupled with a MicroLive Multi Format camera and the software MicroLive (v4.0). In addition, differential interference contrast (DIC) images were taken with an Axisokop (Carl Zeiss, Jena, Germany). This was carried out for cultures on solidified and liquid BG11 as well as BG11 $1_{0}$ medium without nitrogen to enhance the growth of heterocytes [20]. Two hundred images were taken from the strain and the length and widths of the cells were measured for 50 cells with MicroLive (v4.0). Digital drawings were made with a touchpad tablet (Ugee M708) and Adobe Photoshop CS6 based on microscopic images.

\subsection{DNA Extraction, Amplification and Sequencing}

Genomic DNA of the strain Fischerella ambigua 108b/ CCAP1427/4/ 97.28 was extracted from unialgal cultures as described by Williams et al. [21]. Nucleotide sequences of the 16S rRNA gene together with the 16S-23S ITS region (1700-2300 bases) were amplified as described by Marin et al. [22] using the primers SSU-4-forw and ptLSU C-D-rev. The $r b c L X$ gene region (1200 bases) was amplified using the primers rbcLX-CW and rbcLX-CX as described by Rudi et al. [23].

The quality of the polymerase chain reaction (PCR) products were checked by means of agarose gel electrophoresis using $1 \%(w / v)$ agarose and subsequently purified with the NucleSpin Gel and PCR Clean-up Kit (Macherey-Nagel GmbH \& Co. KG, Düren, Germany) following the DNA and PCR clean up protocol. The purified PCR products were sent to Genewiz (Germany $\mathrm{GmbH}$, Leipzig, Germany) for Sanger sequencing with the primers SSU-4-for, Wil 6, Wil 12, Wil 14, Wil 5, Wil 9, Wil16, and ptLSU C-D-rev [22,24,25] for the $16 \mathrm{~S}$ rRNA and rbclX-CW and rbcLX-CX for the protein coding gene region [23]. The generated sequences were assembled with Geneious Prime (v2021.0.1) software package (Biomatters Limited, New Zealand). The sequences were submitted to the National Center for Biotechnology Information (NCBI) GenBank as stated in the species description.

\subsection{Molecular Characterization}

The assembled 16S rRNA and rbcLX gene sequences obtained from Fischerella ambigua 108b/ CCAP1427/4/ 97.28 and related sequences of cyanobacterial strains cited from GenBank were used for phylogenetic analyses including Gloeobacter violacaeus as outgroup for the 16S rRNA alignment and Synechocystis as outgroup for the rbcLX alignment. Both alignments were prepared applying the Muscle algorithm in Mega X [26].

Finally, 89 nucleotide sequences were used for the phylogenetic comparison including $1502 \mathrm{bp}$ of the 16S rRNA gene as well as 57 nucleotide sequences for the rbcLX calculations including 782 bp characters. Ambiguous regions within each alignment were adjusted 
or removed manually allowing smaller final blocks and gap positions within the final blocks. The evolutionary model that was best suited to the used database was selected on the basis of the lowest AIC value and calculated in Mega X for both gene regions. The phylogenetic tree for the 16S rRNA was finally constructed with Mega X using the evolutionary model RGT+G+I of nucleotide substitutions for the alignment as well as $\mathrm{T} 92+\mathrm{G}+\mathrm{I}$ for the phylogenetic tree of the $r b c L X$ gene region. The maximum likelihood method (ML) with 1000 bootstrap replications was calculated with Mega X and Bayesian phylogenetic analyses with two runs of eight Markov chains were executed for one million generations with default parameters with Mr. Bayes 3.2.1 [27] for both trees. Each analysis reached stationarity (average standard deviation of split frequencies between runs $<0.01$ ) well before the end of the run.

Models of the secondary structure of 16S-23S ITS region of Fischerella ambigua 108b/ CCAP1427/4/ 97.28 were built in comparison to phylogenetic or morphologically related genera such as Fischerella, Brasilonema and Scytonema according to the models proposed in Wilde et al. [28], Romanenko et al. [29] and Johansen et al. [30]. The secondary structures could not be compared to other Symphyonema species as the genetic information of these gene regions does not exist [2]. Helices were folded with the online software RNAstructure Web Server [31].

\subsection{Holotype Preparation}

The species was described following the rules and requirements of the International Code of Nomenclature for algae, fungi, and plants [32]. Furthermore, young (3-week-old) cultures were preserved in $4 \%(v / v)$ formaldehyde, in $15 \mathrm{~mL}$ glass bottles. Preserved material was then deposited in the Herbarium Hamburgense, Hamburg, Germany (HBG024930).

\section{Results}

The strain originally termed Fischerella ambigua 108b/ CCAP1427/4/ 97.28 was found to be unique based on its ecology, morphology, distribution, phylogeny and secondary structures of the 16S-23S ITS gene region and not related to Fischerella ambigua. Instead it showed high relation to the genus Symphyonema but because the combination of diacritical features associated with this species did not correspond with any described species within the genus, we named the strain here as the new species Symphyonema bifilamentata sp. nov. 97.28. The most striking morphological characteristic of S. bifilamentata sp. nov. 97.28 is its clear separation between basal section and lateral branches what is explicitly excluded in the original description of the genus Symphyonema by C.-C. Jao in 1944 and thus requires an emendation of the genus.

\subsection{Taxonomic treatment}

\subsubsection{Symphyonema C-C. Jao 1944; Emend. P. Jung, B. Buedel et M. Lakatos}

Emended diagnosis: Thallus pulvinate or wooly, up to $1.5 \mathrm{~cm}$ thick, greyish blue with multiple densely coiled, or parallel-arranged filaments, sometimes joined into erect fascicles. Filaments irregularly branched, sometimes distinctly morphologically diversified in basal sections and branches. Trichomes uniseriate, isopolar, with vegetative cells usually longer than wide, cylindrical, not constricted or slightly constricted at cross walls, not attenuated towards the ends, with rounded terminal cells. Cell content blue-green, often with granulation of various graininess and/or with prominent vacuole-like rounded structures. Branching of two types, true branching of Y-type (reverse Y-branching originates always from special oblong cells within basal sections, each followed by two shortened cells, from which one divides into one elongated cell that starts the lateral branch) and/or T-type (initiates at two swollen, globose cells with prominent, vacuole-like and granular inclusions that divide into smaller, rounded to isodiametric cells that start the lateral branch) and false-branching of scytonematoid-type (including necridic cells); branching initiates remote from the heterocytes. Sheaths firm, homogeneous or slightly lamellated, yellow-brown 
in color in mature parts. Vegetative cells blue-green in color with slightly granular content. Heterocytes intercalary, cylindrical, solitary. Akinetes not observed. Cell division crosswise to the trichome length. Reproduction mostly by hormogonia, separating from trichome apices or defragmentation of, especially, the lateral branches. A small genus with three species currently taxonomically accepted: S. cavernicolum from a cave in Spain [10], S. kaboorum from the littoral zone of an acidic, coastal oligotrophic lake in Australia [11], the former type species of the genus $S$. sinense [12] from wet, calcareous rocks of China and S. sinense var. minor from Papua New Guinea [13] but without any of them being deposited at culture collections nor available genetic information. Two sequenced isolates from soil in Papua New Guiana that were not taxonomically defined supported the distinct phylogenetic position of this genus [2].

Comments: originally the holotype for the genus Symphyonema was S. sinense Jao C.-C. but there is no culture or preserved material nor genetic information available. As S. bifilamentata closely conforms to descriptions for all species described for the genus we propose S. bifilamentata as new reference for the genus Symphyonema. Following the rules for epitypification established in the International Code for Algae, Fungi and Plants [32] and using the monophyletic species concept, we formally present the epitypification.

Epitype for the genus Symphyonema designated here: HBG-024930, culture material of Symphyonema bifilamentata 97.28 (DSM 112338) preserved in $4 \%$ formaldehyde, Herbarium Hamburgense, Hamburg, Germany.

Epitype strain: Symphyonema bifilamentata 97.28 is available at the culture collection DSMZ Braunschweig, Germany (DSM 112338).

\subsubsection{Symphyonema bifilamentata sp. nov. P. Jung, B. Buedel et M. Lakatos}

Description: Pulvinate macroscopic thallus, up to $1 \mathrm{~cm}$ thick, dark green, wooly, that dyes liquid medium transparent-brownish during aging. Filaments are interwoven, on agar first creeping, later slightly erect and parallel arranged. Two types of filaments can be distinguished from each other, swollen basal branches and thin lateral branches. Basal branches: trichomes 3.3-6.6 $\mu \mathrm{m}$ wide, with necridia, mostly uniseriate, bloated but tapered/waisted towards heterocytes that were always present in medium with and without nitrogen; cells barrel-shaped, rounded, squeezed, constricted at cross-walls, wider than long, 2.4-3.3 (6) $\mu \mathrm{m} \times 1.3-1.7 \mu \mathrm{m}$, coarse granulated, with at least one big vacuole-like structure in each cell, blue-green. Lateral branches: up to $200 \mu \mathrm{m}$ long, uniseriate, without necridia; filaments straight, parallel; regular, not tapered towards the ends, fine granulated, fine vacuolated, cells regular, quadratic or slightly longer than wide, 2-2.3 $\mathrm{m} \times 2-2.8 \mu \mathrm{m}$, very slightly constricted at cross-walls, blue-green; apical tip rounded to slightly conical, yellowish, $2.8 \mu \mathrm{m} \times 1.8 \mu \mathrm{m}$. Branching patterns are of true-branching T-type towards all sides of the basal section and false-branching (scytonematoid). Heterocytes are frequent independent of the culture medium used which occur solitary or rarely in pairs of two. They are thick-walled, yellow, intercalary and rectangular in lateral branches, $2.3 \mu \mathrm{m} \times 3.6-5(8.5) \mu \mathrm{m}$ but sub-globose, squeezed and bloated in basal sections, $2-2.2 \mu \mathrm{m}$ $\times 3.6-3.9 \mu \mathrm{m}$. Sheaths of the trichomes are hyaline, colorless, firm, limited, not lamellated, very tight but ruptured by the apical cells of lateral branches. Mature cultures with limited, hyaline but much wider sheaths. Hormogonia or akinetes were not observed, fragmentation of lateral branches (tips) as main dispersal pattern (Figures 1 and 2; Table 1).

Habitat: shallow soil deepening that was every then and now wet at Mellingen, Switzerland.

Etymology: 'bifilamentata' —'having two types of filaments', due to the clear morphological separation of the species into basal and lateral sections.

Type location: SWITZERLAND-Mellingen, Switzerland isolated by Alfons Zehnder in 1965.

Holotype: The preserved holotype specimen (strain 97.28) is available via the Herbarium Hamburgense, Hamburg, Germany (HBG-024930). It was prepared from the living 
strain which was the source of 16S, ITS, and 23S rRNA gene sequence (GenBank accession number MW565974) and rbcLX (GenBank accession number MW565964).

Reference strain: The reference strain Symphyonema bifilamentata sp. nov. 97.28 is available at the German Collection of Microorganisms and Cell Cultures GmbH (DSMZ) Braunschweig, Germany (DSM 112338). Access is also given via the Culture Collection of Algae and Protozoa (CCAP), Scotland (1427/4) since 2004.

Discrimination against other species: Symphyonema bifilamentata sp. nov. has overall smaller trichomes and cells than S. sinense, S. cavernicolum and S. kaboorum and basal and lateral branches are strictly divaricated and frequently shows heterocytes. Additionally, the basal sections of S. bifilamentata sp. nov. are bloated and tapered towards heterocytes.
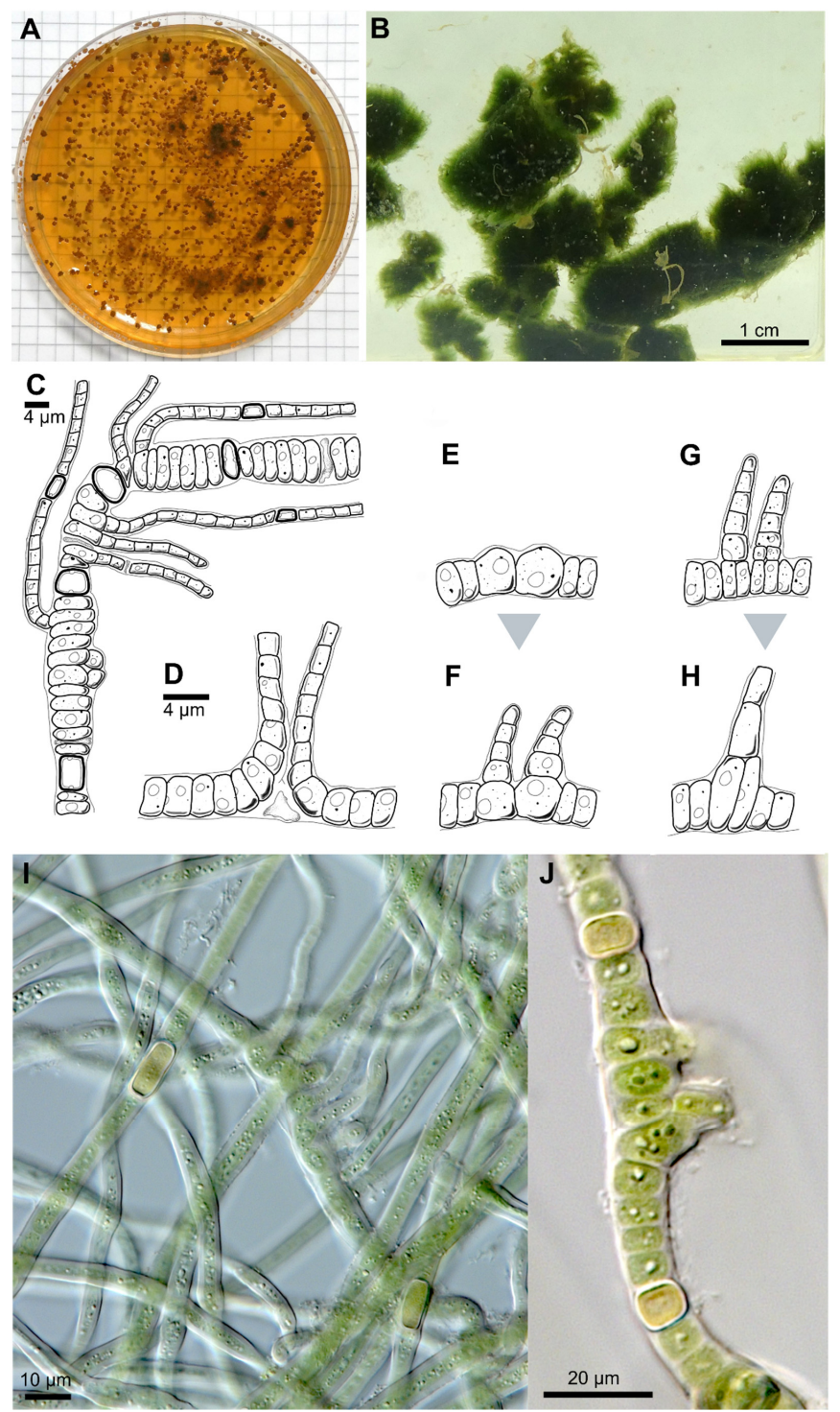

Figure 1. Photographs and drawing of Symphyonema bifilamentata. (A) One-year-old culture on standard BG11 agar with segregated brownish to orange substance that stained the medium. (B) Photograph of mature thallus-like culture in liquid BG11 with fresh medium. (C) Overview drawing of a mature filament showing bloated basal sections with several lateral branches. (D) Scytonematoid type of false branching of young basal section with necridic cell. (E,F) Development of true T-branching with initial swollen basal cells within young basal section in (E) and trapezoidal cells on each basal cells that extend to lateral branches in (F). (G,H) True Y-branching of basal sections with initial stage in $(\mathbf{G})$ and mature filament in $(\mathbf{H}-\mathbf{J})$ show DIC micrographs of mature culture with wider sheaths, multiple branchings and heterocytes. 


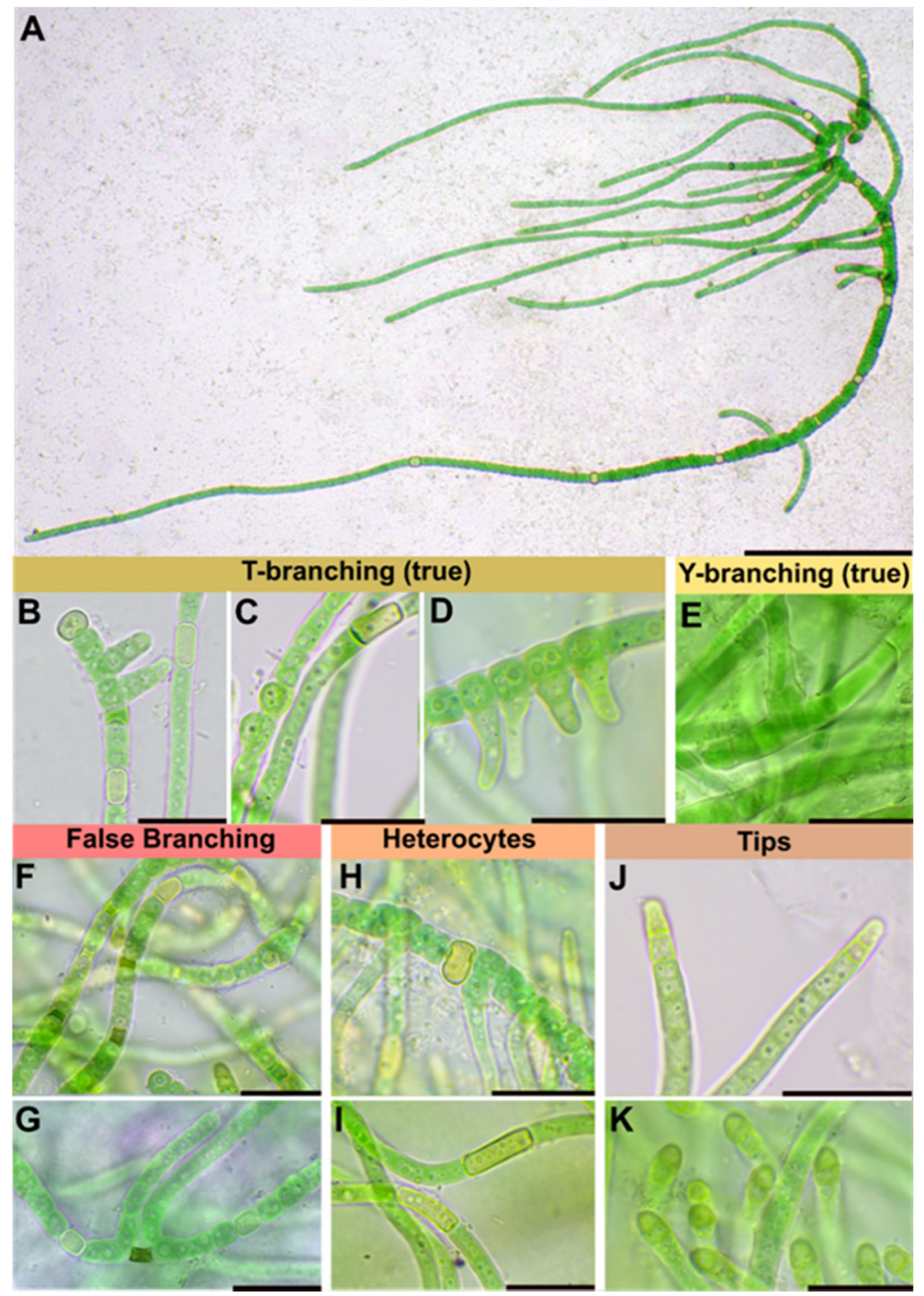

Figure 2. Morphological details of Symphyonema bifilamentata sp. nov. (A) Overview image showing a mature filament growing on agar with swollen basal section that is tapered at heterocytes and several bilateral branches with heterocytes. Scale bar $50 \mu \mathrm{m}$. (B-D) Formation of true T-branching out of young basal sections. $€$ True Y-branching with two elongated cells that unite to a lateral section. $(\mathbf{F}-\mathbf{G})$ Necridic cells in young basal sections in $(\mathbf{F})$ and scytonematoid false branching in $(\mathbf{G})$ where both cells surround a necridic cell form lateral filaments that grow out of the sheath. $(\mathbf{H})$ Squeezed globose heterocyte of basal section. (I) Elongated heterocytes of lateral branches. (J) Yellowish apical cells of young lateral branches and (K) indicating yellowish rounded tips of mature lateral branches. Note fine granulation of lateral sections in $(\mathbf{I}-\mathbf{K})$ compared to the coarse vacuole-like granulation of basal sections in (B-D) and (H). Scale bar of $(\mathbf{B}-\mathbf{K})$ indicates $10 \mu \mathrm{m}$.

Phylogenetic relations and secondary structure of the 16S-23S ITS sequence: Based on the 16S rRNA Symphyonema bifilamentata sp. nov. 97.28 clusters together with Symphyonema sp. 1296-1 and Symphyonema sp. 1517 from soil in Papua New Guinea together with the genus Mastigocladopsis and the Scytonema hyalinum complex Figure 3A. The species is most closely related to Symphyonema sp. 1296-1 (98.73 \%), Symphyonema sp. 1517 (98.41 \%) and Syctonema hyalinum FI5-JRJ03 clone 13 (96.13 \%). Secondary structure of the main informative helices of 16S-23S ITS sequences shows significant differences (Figure 4) in the D1-D1' region and Box B compared to morphological or phylogenetically related taxa such as Fischerella, Brasilonema, and Scytonema. Loops of the D1-D1' and Box B of S. bifilamentata sp. nov. 97.28 are on different positions than those of e.g., Fischerella muscicola SAG 2017, and the 
Box B sequence is shorter than those of the other strains. Secondary structures of other Symphyonemataceae could not be created because no other representative is available in the culture collection nor do there exist molecular data of the corresponding gene regions.
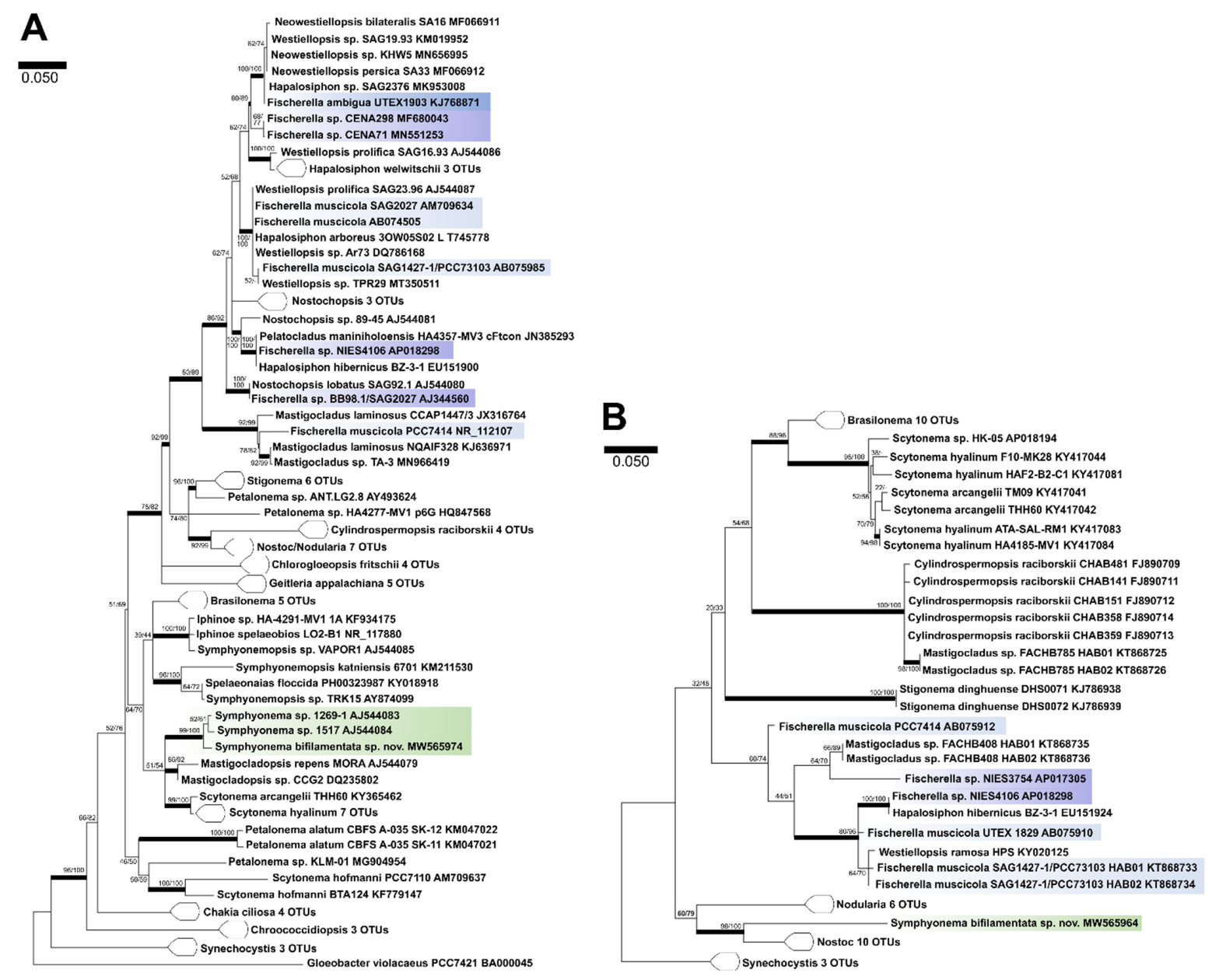

Figure 3. Comparative phylogenetic trees of $16 \mathrm{~S}$ rRNA and protein coding gene region rbcLX. (A) Maximum likelihood (ML) tree obtained from 89 aligned 16S rRNA gene sequences with 1508 bp indicating the position of Symphyonema bifilamentata sp. nov. 97.28 rooted to Gloeobacter violacaeus PCC7421. (B) ML tree from 57 aligned sequences of the protein coding gene region rbcLX with 782 bp rooted to Synechocystis. Numbers on the nodes represent MLand Bayesian bootstrap values respectively, (1000 replicates, each). Bold horizontal lines show lineages supported by at least $75 \%$ of both bootstrap values. Bar represents 0.05 substitutions per nucleotide position. Symphyonema clade is highlighted in green, strains assigned to Fischerella ambigua in dark blue, strains assigned to F. muscicola are marked in light blue and Fischerella strains unassigned to species level are highlighted in purple. 
Table 1. Morphological comparison of Symphyonema species including Fischerella ambigua.

\begin{tabular}{|c|c|c|c|c|c|c|c|c|}
\hline & $\begin{array}{l}\text { Symphyonema sinense } \\
\text { C.-C. Jao }\end{array}$ & $\begin{array}{l}\text { Symphyonema sinense } \\
\text { var. minor C.-C. Jao }\end{array}$ & $\begin{array}{l}\text { Symphyonema } \\
\text { cavernicolum Asencio, } \\
\text { Aboal et Hoffmann }\end{array}$ & $\begin{array}{c}\text { Symphyonema kaboorum G. B. } \\
\text { McGregor }\end{array}$ & $\begin{array}{c}\text { Symphyonema } \\
\text { bifilamentata sp. nov. P. } \\
\text { Jung, B. Buedel et M. } \\
\text { Lakatos }\end{array}$ & $\begin{array}{l}\text { Fischerella ambigua } \\
\text { Kützing ex Bornet et } \\
\text { Flahault) Gomont }\end{array}$ & $\begin{array}{c}\text { Symphyonema sp. } \\
1269-1\end{array}$ & $\begin{array}{l}\text { Symphyonema sp. } \\
1517\end{array}$ \\
\hline Origin & $\begin{array}{c}\text { Aerophytic, wet } \\
\text { calcareous rocks, } \\
\text { Kwangsi, China; Jao } \\
1944\end{array}$ & $\begin{array}{c}\text { Epilithic (subaerial), } \\
\text { granite inselberg } \\
\text { French Guiana; crest of } \\
\text { Montagnes Balenfois } \\
\left(\mathrm{N} 4^{\circ} 5^{\prime}, \mathrm{W} \text {. } 52^{\circ} 42^{\prime} \text { ) 1989; }\right. \\
\text { Sarthou et al., 1995 }\end{array}$ & $\begin{array}{l}\text { Epilithic/chasmoendolithic, } \\
\text { limestone cave, karstic } \\
\text { region, Los Almadenes } \\
\text { gorge, Spain; } \\
\text { Asencio et al., 1996 }\end{array}$ & $\begin{array}{l}\text { Aquatic; surface of large, } \\
\text { submerged } \\
\text { Logs/woody debris in the } \\
\text { littoral zone of an acidic, } \\
\text { coastal oligotrophic lake, } \\
\text { Naree Budjong Djara National } \\
\text { Park, Stradbroke Island, } \\
\text { Queensland, Australia; } \\
\text { McGregor } 2018\end{array}$ & $\begin{array}{l}\text { Edaphic, shallow, hollow, } \\
\text { wet soil, Mellingen, } \\
\text { Switzerland, isolated 1965; } \\
\text { this work }\end{array}$ & $\begin{array}{l}\text { Edaphic, wet, } \\
\text { unpolluted soil, among } \\
\text { mosses; Zurich; } \\
\text { Gomont } 1895\end{array}$ & $\begin{array}{l}\text { Edaphic, soil, Papua } \\
\text { New Guinea, } \\
\text { isolated 1986; Gugger } \\
\text { and Hoffmann, 2004 }\end{array}$ & $\begin{array}{l}\text { Edaphic, soil, Papua } \\
\text { New Guinea, } \\
\text { isolated 1986; Gugger } \\
\text { and Hoffmann, } 2004\end{array}$ \\
\hline Thallus & $\begin{array}{l}\text { Pulvinate, later } \\
\text { expanded, up to } 1.5 \mathrm{~cm} \\
\text { thick, greyish-blue; } \\
\text { filaments parallel } \\
\text { arranged, mostly erect, }\end{array}$ & & $\begin{array}{l}\text { Greyish, interwoven } \\
\text { filaments }\end{array}$ & $\begin{array}{l}\text { Pulvinate, formed by more or } \\
\text { less parallel arranged } \\
\text { filaments }\end{array}$ & $\begin{array}{l}\text { Pulvinate, up to } 1 \mathrm{~cm} \text { thick, } \\
\text { dark green, wooly; } \\
\text { interwoven filaments, on } \\
\text { agar mainly creeping, } \\
\text { parallel arranged rarely } \\
\text { slightly erect; dyes liquid } \\
\text { medium } \\
\text { transparent-brownish }\end{array}$ & $\begin{array}{l}\text { Prostrate, dark brown, } \\
\text { or only in in solitary } \\
\text { filaments }\end{array}$ & Creeping filaments & $\begin{array}{l}\text { Creeping and erect } \\
\text { filaments }\end{array}$ \\
\hline Branching Type & $\begin{array}{l}\text { False-branching } \\
\text { (scytonematoid), } \\
\text { usually solitary, less } \\
\text { frequently geminate }\end{array}$ & $\begin{array}{l}\text { False branching, } \\
\text { true-branching, } \\
\text { reverse-type true } \\
\text { branching }\end{array}$ & $\begin{array}{c}\text { Mainly Y-type, but also } \\
\text { T-type and } \\
\text { false-branching } \\
\text { (scytonematoid) }\end{array}$ & $\begin{array}{l}\text { T- and Y-type true branching, } \\
\text { false-branching } \\
\text { (scytonematoid) }\end{array}$ & $\begin{array}{l}\text { T-type true-branching } \\
\text { towards all sides of the basal } \\
\text { section, false-branching } \\
\text { (scytonematoid) }\end{array}$ & $\begin{array}{l}\text { T- and Y-type true } \\
\text { branching, } \\
\text { false-branching } \\
\text { (scytonematoid) }\end{array}$ & $\begin{array}{l}\text { Mainly Y-type but } \\
\text { also T-type } \\
\text { true-branching and } \\
\text { false-branching } \\
\text { (scytonematoid) }\end{array}$ & $\begin{array}{l}\text { Mainly Y-type but } \\
\text { also T-type } \\
\text { true-branching and } \\
\text { false-branching } \\
\text { (scytonematoid) }\end{array}$ \\
\hline
\end{tabular}


Table 1. Cont.

\begin{tabular}{|c|c|c|c|c|c|c|c|c|}
\hline & $\begin{array}{l}\text { Symphyonema sinense } \\
\text { C.-C. Jao }\end{array}$ & $\begin{array}{l}\text { Symphyonema sinense } \\
\text { var. minor } C .-C \text {. Jao }\end{array}$ & $\begin{array}{c}\text { Symphyonema } \\
\text { cavernicolum Asencio, } \\
\text { Aboal et Hoffmann }\end{array}$ & $\begin{array}{l}\text { Symphyonema kaboorum G. B. } \\
\text { McGregor }\end{array}$ & $\begin{array}{c}\text { Symphyonema } \\
\text { bifilamentata sp. nov. P. } \\
\text { Jung, B. Buedel et M. } \\
\text { Lakatos }\end{array}$ & $\begin{array}{l}\text { Fischerella ambigua } \\
\text { Kützing ex Bornet et } \\
\text { Flahault) Gomont }\end{array}$ & $\begin{array}{c}\text { Symphyonema sp. } \\
1269-1\end{array}$ & $\begin{array}{l}\text { Symphyonema sp. } \\
\qquad 1517\end{array}$ \\
\hline $\begin{array}{l}\text { Basal/main } \\
\text { section }\end{array}$ & $\begin{array}{l}\text { Filaments } 9-12 \mu \mathrm{m} \\
\text { wide, flexuose, } \\
\text { irregularly ramified, } \\
\text { densely intricate; } \\
\text { trichomes } 7-10 \mu \mathrm{m} \\
\text { wide, commonly not } \\
\text { constricted at cross } \\
\text { walls; cells cylindrical, } \\
15-38 \mu \mathrm{m} \text { long, up to } \\
1.5, \text { up to } 3 \times \text { longer } \\
\text { than wide; blue green; } \\
\text { apical cells rounded }\end{array}$ & $\begin{array}{l}\text { Filaments } 8-13 \mu \mathrm{m} \\
\text { without ramification, } \\
\text { simple; cell content } \\
\text { homogeneous, } \\
\text { greenish, cells } \\
\text { cylindrical (6) } 8-14 \mu \mathrm{m} \\
\quad \times 2-4(5) \mu \mathrm{m}\end{array}$ & $\begin{array}{l}\text { No differentiation; } \\
\text { trichomes uniseriate, } \\
\text { constricted at } \\
\text { cross-walls, often } \\
\text { tapering towards ends; } \\
\text { cells irregular barrel } \\
\text { shaped or cylindrical, } \\
\text { isodiametric or longer }\end{array}$ & $\begin{array}{l}\text { Filaments } 11-17 \mu \mathrm{m} \text { wide, } \\
\text { erect, straight to } \\
\text { irregularly flexuous, not } \\
\text { tapered towards the ends, } \\
\text { irregularly ramified, densely } \\
\text { intricate, not constricted at the } \\
\text { cross walls; Vegetative cells } \\
\text { isodiametric, or up to } 4 \times \\
\text { longer than } \\
\text { broad, shorter than broad } \\
\text { towards the apices, (8.5-) } \\
12.5-18.5(-26) \mu \mathrm{m} \text { long } \times \\
4.8-10.5 \mu \mathrm{m} \text { wide, with fine } \\
\text { granular } \\
\text { contents, often vacuolate; } \\
\text { apical cells rounded }\end{array}$ & $\begin{array}{l}\text { Strictly divaricated from } \\
\text { lateral branches; trichomes } \\
3.3-6.6 \mu \mathrm{m} \text { wide, with } \\
\text { necridia, mostly uniseriate, } \\
\text { bloated but } \\
\text { tapered/waisted towards } \\
\text { heterocytes; cells } \\
\text { barrel-shaped, rounded, } \\
\text { squeezed, constricted at } \\
\text { cross-walls, wider than long, } \\
2.4-3.3(6) \mu \mathrm{m} \times 1.3-1.7 \mu \mathrm{m}, \\
\text { coarse granulated, with at } \\
\text { least one big vacuole-like } \\
\text { structure in each cell, } \\
\text { blue-green }\end{array}$ & $\begin{array}{l}\text { Creeping, irregular, } \\
\text { coiled or } \\
\text { flexuouse, 3-7 } \mu \mathrm{m} \\
\text { wide, cylindrical, not or } \\
\text { slightly narrowed } \\
\text { towards ends, } \\
\text { sometimes fasciculated; } \\
\text { monoseriate but } \\
\text { sometimes biseriate, } \\
\text { cells clearly constricted } \\
\text { at cross walls, barrel } \\
\text { shped, up to spherical } \\
3-4 \mu \mathrm{m} \text { wide }\end{array}$ & not evaluated & not evaluated \\
\hline Branches & $\begin{array}{l}\text { Solitary, divaricated } \\
\text { from basal sections }\end{array}$ & & $\begin{array}{l}\text { than wide, } 4-9.6 \mu \mathrm{m} \times \\
4-8 \mu \mathrm{m} \text {; pale blue } \\
\text { green to violet, with } \\
\text { scattered cyanophycin } \\
\text { granules }\end{array}$ & $\begin{array}{l}\text { Slightly narrower than main } \\
\text { filament }\end{array}$ & $\begin{array}{l}\text { Strictly divaricated from } \\
\text { basal sections, up to } 200 \mu \mathrm{m} \\
\text { long, uniseriate, without } \\
\text { necridia; filaments straight, } \\
\text { parallel; regular, not tapered } \\
\text { towards the ends, fine } \\
\text { granulated, fine vacuolated, } \\
\text { cells regular, quadratic or } \\
\text { slightly longer than wide, } \\
2-2.3 \mu \mathrm{m} \times 2-2.8 \mu \mathrm{m} \text {, very } \\
\text { slightly constricted at } \\
\text { cross-walls, blue-green; } \\
\text { apical tip rounded to } \\
\text { slightly conical, yellowish, } \\
2.8 \mu \mathrm{m} \times 1.8 \mu \mathrm{m} \text {; }\end{array}$ & $\begin{array}{l}\text { Cells cylindrical, } \\
2-3 \mu \mathrm{m} \text { wide and up to } \\
4 \times \text { longer than wide, } \\
\text { terminal cells rounded }\end{array}$ & not evaluated & not evaluated \\
\hline Heterocyst & $\begin{array}{l}\text { Solitary, rare, } 12-15 \mu \mathrm{m} \\
\times 8-10, \pm \text { rectangular, } \\
\text { rarely subglobose }\end{array}$ & $\begin{array}{l}\text { Intercalary, cylindrical, } \\
7-13 \mu \mathrm{m} \times 4-6 \mu \mathrm{m}\end{array}$ & $\begin{array}{l}\text { Very rare, intercalary, } \\
\text { cylindrical, } 8.2 \times 5.8 \mu \mathrm{m}\end{array}$ & $\begin{array}{l}\text { solitary, intercalary, rarely } \\
\text { located at the point of } \\
\text { branching, } \\
\text { spherical to elongated } \\
\text { cylindrical, up to } 3.5 \times \text { longer } \\
\text { than broad, } 9.0-18.5(-26) \mu \mathrm{m} \\
\times 5.5-13.8 \mu \mathrm{m}\end{array}$ & $\begin{array}{c}\text { Solitary, rarely in pairs of } \\
\text { two, thick-walled, yellow, } \\
\text { intercalary; rectangular in } \\
\text { branches, } 2.3 \mu \mathrm{m} \times 3.6-5 \\
(8.5) \mu \mathrm{m} ; \text { subglobose, } \\
\text { squeezed and boalated in } \\
\text { basal section, } 2-2.2 \mu \mathrm{m} \times \\
3.6-3.9 \mu \mathrm{m}\end{array}$ & Intercalary, cylindrical & $\begin{array}{l}\text { Intercalary, rarely } \\
\text { lateral-sessile }\end{array}$ & $\begin{array}{l}\text { Intercalary, rarely } \\
\text { lateral-sessile }\end{array}$ \\
\hline Sheath & $\begin{array}{l}\text { Slightly widened, not } \\
\text { or partly slightly } \\
\text { lamellated, initially } \\
\text { hyaline, brownish with } \\
\text { age }\end{array}$ & $\begin{array}{c}\text { Yellow-brownish, } \\
3-4 \mu \mathrm{m} \text { thick, stratified, } \\
\text { marked }\end{array}$ & $\begin{array}{l}\text { Hyaline, often } \\
\text { lamellated, heavily } \\
\text { lime-encrusted }\end{array}$ & $\begin{array}{l}\text { Firm, hyaline } \\
\text { mucilage, up to } 25 \mu \text { m wide, } \\
\text { lamellated closer to the } \\
\text { trichome }\end{array}$ & $\begin{array}{l}\text { Hyaline, colorless, firm, } \\
\text { limited, not lamellated, very } \\
\text { tight, ruptured by the apical } \\
\text { cells of lateral branches; } \\
\text { wider and prominent in } \\
\text { mature cultures }\end{array}$ & $\begin{array}{l}\text { Colorless, up to yellow } \\
\text { brown, lamellated in } \\
\text { old filaments }\end{array}$ & not evaluated & not evaluated \\
\hline Multiplication & $\begin{array}{c}\text { Hormogonia, } 30-35 \mu \mathrm{m} \\
\times 9-10 \mu \mathrm{m}\end{array}$ & $\begin{array}{l}\text { Apical hormogonia, } \\
44-50 \times 7 \mu \mathrm{m}\end{array}$ & Terminal hormogonia & not evaluated & $\begin{array}{l}\text { Fragmentation of lateral } \\
\text { branches }\end{array}$ & Long hormogonia & Hormogonia & Hormogonia \\
\hline
\end{tabular}




\section{Discussion}

\subsection{Taxonomic Significance}

The Symphyonemataceae appear to be an interesting family comprising 11 genera of true-branching heterocytous cyanobacteria of which only a few species were studied using molecular methods including data of the 16S rRNA gene of the type species [3]. Surprisingly, this still holds true although a lot has changed in the systematics of cyanobacteria throughout the last decades fueled by modern sequencing techniques and a plethora of studies that include isolation of strains.

In addition, for the genus Symphyonema there is no genetic information from neither the type species S. sinense [12], nor for any of the described species such as S. kaboorum [11], S. cavernicolum [10] or S. cavernicolum var. minor [13] available. However, the previous authors described their findings well based on morphological features which allows a presumably correct assignment of the species to this genus and discrimination among those species. From a holistic point of view, the two isolates Sympyhonema sp. 1269-1 and 1517 from soil of Papua New Guinea [2] acted as well-supported entities that bridged the gap between the morphological establishment of the genus and genetically captured strains. However, the picture of the genus Symphyonema was still incomplete since the two strains were not deposited at any culture collection and thus cannot be evaluated in the context of the exacting, rule-bound taxonomic agreement. Finally, this work establishes a valid fixpoint of the genus with S. bifilamentata sp. nov. 97.28 as an isolate of known origin, trackable history, morphological evaluation, poly-genetic analyses and granted access via several culture collections.

In contrast to its original morphology-based assignment to Fischerella ambigua in 1965, the strain clustered distantly from the family Hapalosiphonaceae including several species of Fischerella in the ML tree of the $16 \mathrm{~S}$ rRNA (Figure 3A), but appeared in close relation to sequences of Symphyonema sp. 1269-1 and 1517, with $>98 \%$ similarity. Interestingly, the three Symphyonema sequences form a bigger cluster (Figure 3A) together with the true-branching Mastigocladopsis, and the false branching Scytonema hyalinum complex ( $<96 \%$ similarity) that again demonstrates the polyphyly of true-branching heterocytous taxa, formerly classified as Stigonematales. The protein coding gene region $r b c L X$ of Symphyonema bifilamentata sp. nov. 97.28 shows a single position of the sequence in the ML tree but here it clusters together with the genera Nostoc and Nodularia (Figure 3B). This appears confusing but it needs to be mentioned that the nucleotide data bases currently hold only a limited amount of sequences of this gene region for comparisons. Information about this gene region from highly related taxa such as Mastigocladopsis are missing which explains the single position of the $r b c L X$ sequence of our strain. However, this gene region is proved to be a significant discrimination feature especially within the Nostocales because it is a single copy gene of approximately 1430 base pairs which is free from length mutations except at the far $3^{\prime}$ end with a fairly conservative rate of evolution [33].

The separation from other Symphyonema species can also be supported by examination of morphological features. For example, the prominent differentiation into main and lateral branches (Figure 2A) together with the bloated parts of the main sections tapered by heterocytes (Figure 1C; Figure 2A) allows a strict separation (Table 1) from other Symphyonema species. However, this separation is also supported by the different ecology of the species, regarding the studied strain, collected from soil in Switzerland where it survives temperatures below $0{ }^{\circ} \mathrm{C}$ during winter. While the other species are from rather ice free areas such as from granitic rocks in French Guiana (S. sinense var. minor), low-light cave in Spain (S. cavernicolum), calcareous rocks in China (S. sinense) and an acidic, coastal oligotrophic lake in Australia (S. kaboorum). 


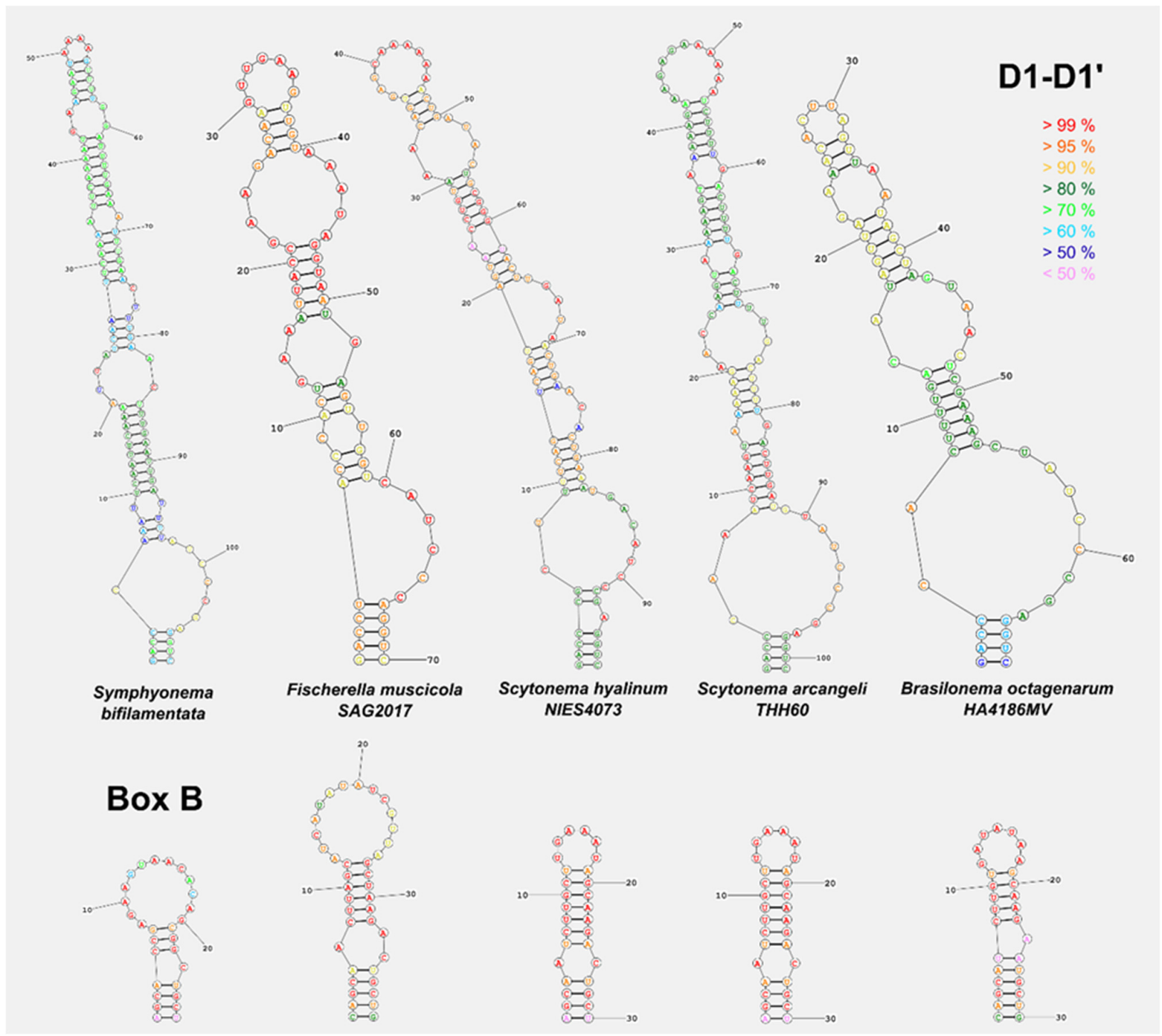

Figure 4. Predicted secondary RNA structures of the main informative helices of the 16S-23S ITS region (D1-D1' and Box B) of Symphyonema bifilamentata sp. nov. 97.28 in comparison with the closest strains in terms of phylogenetic position and morphology. Color code indicates the probability in percent of the calculated base position.

The initial description of the strain $108 \mathrm{~b}$ as Fischerella ambigua was on the one hand probably misguided by the fact that the locality of the type strain of F. ambigua was Zurich, Switzerland [34] and the location of the strain 108b was also based in Switzerland, only ca. $30 \mathrm{~km}$ away at Mellingen. With the knowledge about cyanobacteria at the time strain 108b was found, it was much more likely that it resembled a cyanobacterial species from the same sampling area than a species that was once found in Asia. On the other hand F. ambigua and S. bifilamentata share some basic morphological features but can be distinguished based on e.g., the multiseriate filaments found in F. ambigua that were part of the first description [34] and investigated elsewhere [35]. In 1965 the situation might have also been complicated by the fact that the description of Symphyonema was published in an Asian magazine [12] while literature about F. ambigua was available in French [34], which was much more accessible to the Swiss isolator.

\subsection{Bioactive Compound Biosynthesis: Symphyonema vs. Fischerella}

The true-branching cyanobacterial genera in the Nostocales were first investigated for their production of novel natural products in the mid-1980s, mainly spurred by the work of Prof. Richard E. Moore [36]. The biosynthetic potential of these organisms has since also been observed at the genome level, with large numbers of biosynthetic gene clusters being 
identified throughout the order, despite the limited number of sequenced genomes [37]. Within the true-branching genera of the Nostocales, the majority of cyanobacterial isolates belong to the genus Fischerella and these provide a significant proportion of structurally intriguing bioactive products limited to this order (Figure 5; Table 2). Interestingly, while the majority of true-branching genera of the Nostocales have been isolated from freshwater or terrestrial environments, they appear to produce an extraordinary array of halogenated bioactive products. The presence of halogen substituents often enhances the bioactivity of these products [38] and, therefore, the true-branching Nostocales, especially Fischerella, have been greatly focused upon in natural product discovery efforts.

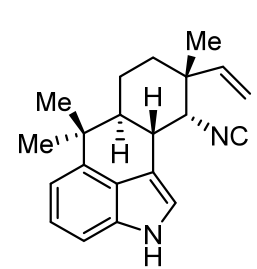

Hapalindole U

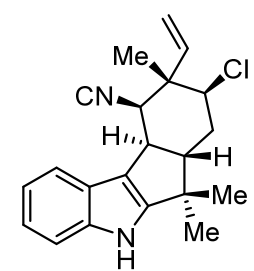

Fischerindole L

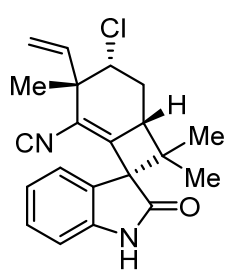

Welwitindolinone A

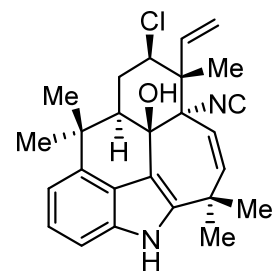

Ambiguine $\mathrm{K}$

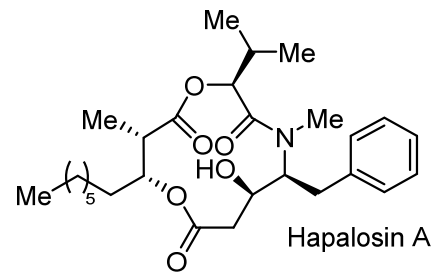<smiles>CCCCCC#CC#C/C=C/CC(C)C[C@@H]1C[C@H](C)/C(=C2/C(=O)C(C)N(C)C2=O)N1</smiles>

Fischerellin A<smiles>Clc1ccc2[nH]c3c(ccc4c5cc(Cl)ccc5[nH]c43)c2c1</smiles>

Tjipanazole D<smiles>Oc1c(Cl)cc(Cl)cc1-c1c(Cl)cc(Cl)c(Oc2ccc(Cl)cc2Cl)c1O</smiles>

Figure 5. Representative chemical structures from Symphyonema bifilamentata sp. nov. 97.28 and various strains of Fischerella.

By far the largest group of bioactive products reported from the Fischerella genus are the hapalindole-like family of indole alkaloids [39], which consist of more than 80 analogues divided into four subgroups, including the hapalindoles, fischerindoles, ambiguines, and the welwitindoliones, each with characteristic oxidation and cyclisation patterns (Figure 5 for representative examples). The hapalindole-like family is dispersed throughout the true-branching genera of Nostocales including Hapalosiphon, Westiella, Westiellopsis, and most commonly Fischerella. Only one other class of bioactive products, the hapalosins, have been reported across two different genera within the Nostocales, initially reported from Hapalosiphon welwitischii IC-52-3 [37,40] and more recently in Fischerella sp. PCC9431 [41,42]. Two groups of bioactive products, the ultraviolet (UV) sunscreen mycosporine-like amino acids and the hepatotoxic microcystins, are broadly distributed across the cyanobacterial phylum including Fischerella [43-45]. Several other bioactive compounds including the fischerellins $[46,47]$ parsiguine, and the aranazoles $[48,49]$ appear to be strictly limited to production by Fischerella. Importantly, all of the natural products described within the Fischerella genus do not appear to be produced by Symphyonema bifilamentata sp. nov. 97.28.

The ambigols, 2,4-dichlorobenzoic acid and the tjipanazoles were originally reported from extracts of Fischerella ambigua 108b (now Symphyonema bifilamentata spec. nov. 97.28) in the early 90 s and mid-2000s $[14,15,50]$ and recently also accessed by total synthesis [51]. The ambigols are polyhalogenated triphenols that are composed of dechlorinated phenol building blocks are linked by biaryl or biaryl ether bonds. While they are structurally related to the polybrominated diphenyls recently reported from marine cyanobacteria $[52,53]$, 
they remain biosynthetically unrelated [17]. Furthermore, the ambigols were reported to possess a range of bioactivities including antifungal, antibacterial and molluscicidal, as well as having been implicated in the increase of the quorum-sensing regulated red pigment prodigiosin. The tjipanazoles are halogenated bis-indole alkaloids with some structural similarities to the bioactive staurosporines from Streptomyces [54]. Several tjipanazoles were observed to have in vitro antifungal activity as well as weak cytotoxicity. With the only exception of the identification of several tjipanazole analogues from Tolypothrix tjipanasensis [55], all three groups of molecules have exclusively been identified in Fischerella ambigua 108b (Symphyonema bifilamentata sp. nov. 97.28).

Since the initial discovery of the ambigols and tjipanazoles, these molecules have not been discovered in any other Fischerella strain. The biosynthetic gene cluster for both the ambigols $(a b)$ and tjipanazoles $(t j p)$ were recently characterised by Duell et al., [17] and Chilczuk et al., [18], respectively. To determine if other organisms may have the genetic capability to produce these molecules, we performed a bioinformatic screening across all genomes within the NCBI database using cblaster [56]. This revealed that currently the $a b$ or tpj gene clusters cannot be found in any organism other than Symphyonema bifilamentata sp. nov. 97.28 , indicating the biosynthetic gene clusters are not present in the currently available genomes of Fischerella. This finding highlights that the chances of discovering novel metabolites are greater by examining strains from new genera rather than additional representatives within the same genus, an idea that was recently supported also for other bacteria [57]. These results, in combination with the natural products isolation literature presented here (Table 2), provide support for a clear distinction between the secondary metabolism of Fischerella and Symphyonema bifilamentata sp. nov. 97.28 further highlighting the allocation of this organism into a separate genus. 
Table 2. Summary of natural products produced by Symphyonema bifilamentata 97.28 compared to those produced by related species from literature.

\begin{tabular}{|c|c|c|c|c|}
\hline Compound Family & Producing Organism & Natural Product Class & Proposed Bioactivity & Reference \\
\hline Ambigols & Symphyonema bifilamentata 97.28 & Polyhalogenated aromatics & Antibiotic, antifungal, molluscicidal & {$[14-17,58]$} \\
\hline 2,4-dichlorobenzoic acid & Symphyonema bifilamentata 97.28 & & & [15] \\
\hline Tjipanazoles & $\begin{array}{c}\text { Symphyonema bifilamentata } 97.28 \\
\text { Tolypothrix tjipanasensis }\end{array}$ & indolo[2,3-a]carbazoles & Antifungal & {$[18,55,59]$} \\
\hline Aranazoles & Fischerella sp. PCC 9339 & Halogenated NRPS/PKS & & [49] \\
\hline \multirow[t]{2}{*}{ Fischerellins } & Fischerella muscicola & Aminoacylpolyketide & Antifungal, herbicidal & \multirow{2}{*}[46,47,60,61]{} \\
\hline & Westiellopsis sp. SAG 20.93 & & & \\
\hline Ambiguines & $\begin{array}{c}\text { Fischerella sp. } \\
\text { Fischerella ambigua } \\
\text { Fischerella ambigua UTEX } 1903 \\
\text { Hapalosiphon sp. } \\
\text { Hapalosiphon delicatulus } \\
\text { Hapalosiphon hibemicus BZ-3-1 Westiellopsis prolifica } \\
\text { EN-3-1 }\end{array}$ & Halogenated Indole alkaloid & Antimicrobial, phytotoxic & {$[62-67]$} \\
\hline Fischerindoles & $\begin{array}{l}\text { Fischerella sp. SAG } 46.79 \\
\text { Fischerella muscicola } \\
\text { Fischerella muscicola UTEX } 1829\end{array}$ & Halogenated Indole alkaloids & Antifungal & {$[60,68]$} \\
\hline Hapalindoles & $\begin{array}{c}\text { Fischerella ambigua UTEX } 1903 \\
\text { Fischerella sp. } \\
\text { Fischerella sp. CENA } 19 \\
\text { Fischerella muscicola UTEX LB1829 } \\
\text { Westiellopsis sp. SAG } 20.93\end{array}$ & Halogenated Indole alkaloids & Insecticidal & {$[61,66,69-72]$} \\
\hline Welwitindolinones & $\begin{array}{c}\text { Fischerella muscicola } \text { HG-39-5 } \\
\text { Fischerella major } \text { HX-7-4 } \\
\text { Hapalosiphon welwitschii IC-52-3 Westiella intricata } \\
\text { HT-29-1 } \\
\end{array}$ & Halogenated Indole alkaloids & & {$[40,73]$} \\
\hline Hapalindolinones & Fischerella sp. ATCC 52558 & Indole alkaloids & & [74] \\
\hline 13-hydroxydechlorofontonamide & Fischerella muscicola UTEX LB1829 & Indole alkaloids & & [61] \\
\hline Mycosporine-like amino acids & $\begin{array}{l}\text { Fischerella sp. PCC9339 } \\
\quad \text { Fischerella sp. } 9431\end{array}$ & & & [43] \\
\hline Microcystins & $\begin{array}{l}\text { Fischerella sp. NQAIF311 } \\
\text { Fischerella sp. CENA161 } \\
\text { Fischerella major }\end{array}$ & NRPS/PKS & Hapatotoxin & {$[44,45,75,76]$} \\
\hline Parsiguine & Fischerella ambigua PTCC 1635 & & Antimicrobial & [48] \\
\hline Hapalosin & $\begin{array}{l}\text { Hapalosiphon welwitschii IC-52-3 } \\
\text { Fischerella sp. PCC9431 }\end{array}$ & NRPS/PKS & Multidrug-resistance reversing activity & {$[37,40-42]$} \\
\hline
\end{tabular}




\section{Conclusions}

Our study demonstrates the importance of combining classical taxonomical work in order to correctly interpret the identification of natural products such as bioactive compounds produced by microalgae and their potential applications. This includes the whole workflow from isolating, evaluating ecological factors from the original environment, taxonomic work ranging from classical morphology to genetics, as well as the deposition of authentic strains in public culture collections. Moreover, the combination of these and biochemical methods not only help to separate taxa, but also indicate the probability to find new metabolic pathways and thus compound families. The authors want to encourage also those who conduct studies on cyanobacterial strains to carefully evaluate the taxonomic character of their strains, because this allows a correct assignment of results in comparison to related strains, genera or species.

Author Contributions: Conceptualization, P.J. and M.L.; methodology, P.J. and P.M.D.; writingoriginal draft preparation, P.J.; writing - review and editing, B.B.; M.L. and P.M.D.; visualization, P.J., B.B. and P.M.D.; supervision, M.L. and B.B.; funding acquisition, M.L. All authors have read and agreed to the published version of the manuscript.

Funding: This research was funded by the European Regional Development Fund ERDF Photoproma (ERDF-EC Ref. 84003265).

Institutional Review Board Statement: Not applicable.

Informed Consent Statement: Not applicable.

Data Availability Statement: Generated sequences can be found as stated under the species description.

Conflicts of Interest: The authors declare no conflict of interest.

\section{References}

1. Anagnostidis, K.; Komárek, J. Modern approach to the classification system of Cyanophytes 5-Stigonematales. Archiv Für Hydrobiol. 1990, 86, 1-73.

2. Gugger, M.F.; Hoffmann, L. Polyphyly of true branching cyanobacteria (Stigonematales). Int. J. Syst. Evol. Microbiol. 2004, 54, 349-357. [CrossRef]

3. Komárek, J.; Kaštovský, J.; Mareš, J.; Johansen, J. Taxonomic classification of cyanoprokaryotes (cyanobacterial genera) 2014, using a polyphasic approach. Preslia 2014, 86, 295-335.

4. Bauersachs, T.; Miller, S.R.; Gugger, M.; Mudimu, O.; Friedl, T.; Schwark, L. Heterocyte glycolipids indicate polyphyly of stigonematalean cyanobacteria. Phytochemistry 2019, 166, 112059. [CrossRef] [PubMed]

5. Alcorta, J.; Vergara-Barros, P.; Antonaru, L.A.; Alcamán-Arias, M.E.; Nürnberg, D.J.; Díez, B. Fischerella thermalis: A model organism to study thermophilic diazotrophy, photosynthesis and multicellularity in cyanobacteria. Extremophiles 2019, 23, 635-647. [CrossRef]

6. Castenholz, R.W. The thermophilic cyanophytes of Iceland and the upper temperature limit. J. Phycol. 1969, 5, 360-368. [CrossRef]

7. Kaštovský, J.; Johansen, J.R. Mastigocladus laminosus (Stigonematales, Cyanobacteria): Phylogenetic relationship of strains from thermal springs to soil-inhabiting genera of the order and taxonomic implications for the genus. Phycologia 2008, 47, 307-320. [CrossRef]

8. Lamprinou, V.; Christodoulou, M.; Hernandez-Marine, M.; Parmakelis, A.; Economou-Amilli, A. Spelaeonaias gen. nov., a new true-branched cyanobacterium from Cave Vlychada (Diros, Peloponnese, Greece). Phytotaxa 2016, 282, 171-185. [CrossRef]

9. Friedmann, E.I. Geitleria calcarea n. gen. et n. sp.: A new Atmophytic Lime-incrusting Blue-green Alga. Botaniska Notiser 1955, $108,439-445$.

10. Asencio, A.D.; Aboal, M.; Hoffmann, L. A new cave-inhabiting blue-green alga: Symphyonema cavernicolum sp. nova (Mastigocladaceae, Stigonematales). Algol. Stud. Arch. für Hydrobiol. 1996, 83, 73-82. [CrossRef]

11. McGregor, G.B. Freshwater Cyanobacteria of North-Eastern Australia: 3. Nostocales. Phytotaxa 2018, 359, 1-166. [CrossRef]

12. Jao, C.-C. Studies on the fresh-water algae of China, XIII New Myxophyceae from Kwangsi. Sinensia 1944, 15, 75-90.

13. Sarthou, C.; Thérézien, Y.; Couté, A. Cyanophycées de l'inselberg des Nouragues (Guyane française). Nova Hedwig. 1995, 61, 85-109.

14. Falch, B.S.; Koenig, G.M.; Wright, A.D.; Sticher, O.; Ruegger, H.; Bernardinelli, G. Ambigol A and B: New biologically active polychlorinated aromatic compounds from the terrestrial blue-green alga Fischerella ambigua. J. Org. Chem. 1993, 58, 6570-6575. [CrossRef] 
15. Wright, A.D.; Papendorf, O.; König, G.M. Ambigol C and 2, 4-Dichlorobenzoic Acid, Natural Products Produced by the Terrestrial Cyanobacterium Fischerella ambigua. J. Nat. Prod. 2005, 68, 459-461. [CrossRef]

16. Chilczuk, T.; Monson, R.; Schmieder, P.; Christov, V.; Enke, H.; Salmond, G.; Niedermeyer, T.H.J. Ambigols from the Cyanobacterium Fischerella ambigua increase Prodigiosin Production in Serratia spp. ACS Chem. Biol. 2020, 15, 2929-2936. [CrossRef]

17. Duell, E.R.; Milzarek, T.M.; El Omari, M.; Linares-Otoya, L.J.; Schäberle, T.F.; König, G.M.; Gulder, T.A. Identification, cloning, expression and functional interrogation of the biosynthetic pathway of the polychlorinated triphenyls ambigol A-C from Fischerella ambigua 108b. Org. Chem. Front. 2020, 7, 3193-3201. [CrossRef]

18. Chilczuk, T.; Schäberle, T.F.; Vahdati, S.; Mettal, U.; El Omari, M.; Enke, H.; Wiese, M.; König, G.M.; Niedermeyer, T.H.J. Halogenation-guided chemical screening provides insight into tjipanazole biosynthesis by the cyanobacterium Fischerella ambigua. ChemBioChem 2020, 21, 2170-2177. [CrossRef]

19. Hyde, K.D.; Zhang, Y. Epitypification: Should we epitypify? J. Zheijang Univ. Sci. B 2008, 9, 842-846. [CrossRef]

20. Stanier, R.Y.; Kunisawa, R.; Mandel, M.; Cohen-Bazire, G. Purification and properties of unicellular blue-green algae (Order Chroococcales). Bacteriol. Rev. 1971, 35, 171-205. [CrossRef]

21. Williams, L.; Jung, P.; Zheng, L.J.; Maier, S.; Peer, T.; Grube, M.; Weber, B.; Büdel, B. Assessing recovery of biological soil crusts across a latitudinal gradient in Western Europe. Rest. Ecol. 2017, 26, 543-554. [CrossRef]

22. Marin, B.; Nowack, E.; Melkonian, M. A plastid in the making: Evidence for a second primary endosymbiosis. Protist 2005, 156, 425-432. [CrossRef] [PubMed]

23. Rudi, K.; Skulberg, O.M.; Jakobsen, K.S. Evolution of cyanobacteria by exchange of genetic material among phyletically related strains. J. Bact. 1998, 180, 3453-3461. [CrossRef] [PubMed]

24. Wilmotte, A.; Van der Auwera, G.; De Wachter, R. Structure of the $16 \mathrm{~S}$ ribosomal RNA of the thermophilic cyanobacterium Chlorogloeopsis HTF ("Mastigocladus laminosus HTF") strain PCC7518, and phylogenetic analysis. FEBS Lett. 1993, 317, 96-100. [CrossRef]

25. Mikhailyuk, T.I.; Vinogradova, O.N.; Glaser, K.; Karsten, U. New taxa for the flora of Ukraine, in the context of modern approaches to taxonomy of Cyanoprokaryota/Cyanobacteria. Int. J. Algae 2016, 18, 301-320. [CrossRef]

26. Kumar, S.; Stecher, G.; Li, M.; Knyaz, C.; Tamura, K. MEGA X: Molecular evolutionary genetics analysis across computing platforms. Mol. Biol. Evol. 2018, 35, 1547-1549. [CrossRef] [PubMed]

27. Ronquist, F.; Huelsenbeck, J.P. MrBayes 3: Bayesian phylogenetic inference under mixed models. Bioinformatics 2003, 19, 1572-1574. [CrossRef] [PubMed]

28. Wilde, S.B.; Johansen, J.R.; Wilde, H.D.; Jiang, P.; Bartelme, B.; Haynie, R.S. Aetokthonos hydrillicola gen. et sp. nov.: Epiphytic cyanobacteria on invasive aquatic plants implicated in Avian Vacuolar Myelinopathy. Phytotaxa 2014, 181, 243-260. [CrossRef]

29. Romanenko, P.A.; Vinogradova, O.N.; Romanenko, E.A.; Mikhailyuk, T.I.; Babenko, L.M.; Ivannikov, R.; Scherbak, N.N. Morphological and Molecular Characterization of the Representative of Brasilonema (Scytonemataceae, Cyanoprokaryota) from the Tropical Greenhouse in Kiev (Ukraine). Int. J. Algae 2020, 22, 103-122. [CrossRef]

30. Johansen, J.R.; Mareš, J.; Pietrasiak, N.; Bohunická, M.; Zima, J., Jr.; Štenclová, L.; Hauer, T. Highly divergent $16 \mathrm{~S}$ rRNA sequences in ribosomal operons of Scytonema hyalinum (Cyanobacteria). PLoS ONE 2017, 12, e0186393. [CrossRef]

31. Reuter, J.S.; Mathews, D.H. RNAstructure: Software for RNA secondary structure prediction and analysis. BMC Bioinform. 2010, 11, 129. [CrossRef]

32. Turland, N.J.; Wiersema, J.H.; Barrie, F.R.; Greuter, W.; Hawksworth, D.L.; Herendeen, P.S.; Knapp, S.; Kusber, W.H.; Li, D.Z.; Marhold, K.; et al. International Code of Nomenclature for Algae, Fungi, and Plants (Shenzhen Code) Adopted by the Nineteenth International Botanical Congress Shenzhen, China, July 2017; Regnum Vegetabile 159; Koeltz Botanical Books: Glashütten, Germany, 2018; p. 159.

33. Singh, P.; Fatma, A.; Mishra, A.K. Molecular phylogeny and evogenomics of heterocystous cyanobacteria using rbcl gene sequence data. Ann. Microbiol. 2015, 65, 799-807. [CrossRef]

34. Gomont, M.A. Note sur le Scytonema ambiguum Kützing. J. Bot. 1895, 9, 49-52.

35. Thurston, E.L.; Ingram, L.O. Morphology and fine structure of Fischerella ambigua. J. Phycol. 1971, 7, 203-210. [CrossRef]

36. Moore, R.E.; Cheuk, C.; Patterson, G.M. Hapalindoles: New alkaloids from the blue-green alga Hapalosiphon fontinalis. J. Am. Chem. Soc. 1984, 106, 6456-6457. [CrossRef]

37. Micallef, M.L.; D’Agostino, P.M.; Sharma, D.; Viswanathan, R.; Moffitt, M.C. Genome mining for natural product biosynthetic gene clusters in the Subsection V cyanobacteria. BMC Genom. 2015, 16, 1-20. [CrossRef] [PubMed]

38. Naumann, K. Influence of chlorine substituents on biological activity of chemicals: A review. Pest Manag. Sci. Former. Pestic. Sci. 2000, 56, 3-21. [CrossRef]

39. Bhat, V.; Dave, A.; MacKay, J.A.; Rawal, V.H. The chemistry of hapalindoles, fischerindoles, ambiguines, and welwitindolinones. Alkaloids Chem. Biol. 2014, 73, 65-160. [PubMed]

40. Stratmann, K.; Burgoyne, D.L.; Moore, R.E.; Patterson, G.M.; Smith, C.D. Hapalosin, a cyanobacterial cyclic depsipeptide with multidrug-resistance reversing activity. J. Org. Chem. 1994, 59, 7219-7226. [CrossRef]

41. D'Agostino, P.M.; Gulder, T.A. Direct pathway cloning combined with sequence-and ligation-independent cloning for fast biosynthetic gene cluster refactoring and heterologous expression. ACS Synth. Biol. 2018, 7, 1702-1708. [CrossRef] 
42. Pereira, J.O.; de Souza, A.Q.L.; de Souza, A.D.L.; de Castro França, S.; de Oliveira, L.A. Overview on biodiversity, chemistry, and biotechnological potential of microorganisms from the Brazilian Amazon. In Diversity and Benefits of Microorganisms from the Tropics; Springer: Cham, Switzerland, 2017; pp. 71-103.

43. Yang, G.; Cozad, M.A.; Holland, D.A.; Zhang, Y.; Luesch, H.; Ding, Y. Photosynthetic production of sunscreen shinorine using an engineered cyanobacterium. ACS Synth. Biol. 2018, 7, 664-671. [CrossRef]

44. Cirés, S.; Alvarez-Roa, C.; Wood, S.A.; Puddick, J.; Loza, V.; Heimann, K. First report of microcystin-producing Fischerella sp. (Stigonematales, Cyanobacteria) in tropical Australia. Toxicon 2014, 88, 62-66. [CrossRef] [PubMed]

45. Fiore, M.F.; Genuário, D.B.; da Silva, C.S.P.; Shishido, T.K.; Moraes, L.A.B.; Neto, R.C.; Silva-Stenico, M.E. Microcystin production by a freshwater spring cyanobacterium of the genus Fischerella. Toxicon 2009, 53, 754-761. [CrossRef]

46. Hagmann, L.; Jüttner, F. Fischerellin A, a novel photosystem-II-inhibiting allelochemical of the cyanobacterium Fischerella muscicola with antifungal and herbicidal activity. Tetrahedron Lett. 1996, 37, 6539-6542. [CrossRef]

47. Papke, U.; Gross, E.M.; Francke, W. Isolation, identification and determination of the absolute configuration of Fischerellin, B. A new algicide from the freshwater cyanobacterium Fischerella muscicola (Thuret). Tetrahedron Lett. 1997, 38, 379-382. [CrossRef]

48. Ghasemi, Y.; Yazdi, M.T.; Shafiee, A.; Amini, M.; Shokravi, S.; Zarrini, G. Parsiguine, a novel antimicrobial substance from Fischerella ambigua. Pharm. Biol. 2004, 42, 318-322. [CrossRef]

49. Moosmann, P.; Ueoka, R.; Gugger, M.; Piel, J. Aranazoles: Extensively Chlorinated Nonribosomal Peptide-Polyketide Hybrids from the Cyanobacterium Fischerella sp. PCC 9339. Org. Lett. 2018, 20, 5238-5241. [CrossRef]

50. Wagner, C.; Molitor, I.M.; König, G.M. Critical view on the monochlorodimedone assay utilized to detect haloperoxidase activity. Phytochemistry 2008, 69, 323-332. [CrossRef] [PubMed]

51. Milzarek, T.M.; Gulder, T.A. Total Synthesis of the Ambigols: A Cyanobacterial Class of Polyhalogenated Natural Products. Org. Lett. 2021, 23, 102-106. [CrossRef]

52. Agarwal, V.; Blanton, J.M.; Podell, S.; Taton, A.; Schorn, M.A.; Busch, J.; Moore, B.S. Metagenomic discovery of polybrominated diphenyl ether biosynthesis by marine sponges. Nat. Chem. Biol. 2017, 13, 537-543. [CrossRef] [PubMed]

53. Agarwal, V.; El Gamal, A.A.; Yamanaka, K.; Poth, D.; Kersten, R.D.; Schorn, M.; Moore, B.S. Biosynthesis of polybrominated aromatic organic compounds by marine bacteria. Nat. Chem. Biol. 2014, 10, 640-647. [CrossRef]

54. Onaka, H.; Tanifguchi, S.I.; Igarashi, Y.; Furumai, T. Cloning of the staurosporine biosynthetic gene cluster from Streptomyces sp. TP-A0274 and its heterologous expression in Streptomyces lividans. J. Antib. 2002, 55, 1063-1071. [CrossRef]

55. Bonjouklian, R.; Smitka, T.A.; Doolin, L.E.; Molloy, R.M.; Debono, M.; Shaffer, S.A.; Patterson, G.M. Tjipanazoles, new antifungal agents from the blue-green alga Tolypothrix Tjipanasensis. Tetrahedron 1991, 47, 7739-7750. [CrossRef]

56. Gilchrist, C.L.M.; Booth, T.J.; Chooi, Y.H.H. cblaster: A remote search tool for rapid identification and visualization of homologous gene clusters. bioRxiv 2020, 11, 370601.

57. Hoffmann, T.; Krug, D.; Bozkurt, N.; Duddela, S.; Jansen, R.; Garcia, R.; Müller, R. Correlating chemical diversity with taxonomic distance for discovery of natural products in myxobacteria. Nat. Commun. 2018, 9, 1-10. [CrossRef]

58. Falch, B.S.; König, G.M.; Sticher, O.; Wright, A.D. Studies on the glycolipid content of the cyanobacterium Fischerella ambigua. Planta Med. 1995, 61, 540-543. [CrossRef] [PubMed]

59. Falch, B.S.; König, G.M.; Wright, A.D.; Sticher, O.; Angerhofer, C.K.; Pezzuto, J.M.; Bachmann, H. Biological activities of cyanobacteria: Evaluation of extracts and pure compounds. Planta Med. 1995, 61, 321-328. [CrossRef]

60. Kim, H.; Krunic, A.; Lantvit, D.; Shen, Q.; Kroll, D.J.; Swanson, S.M.; Orjala, J. Nitrile-containing fischerindoles from the cultured cyanobacterium Fischerella sp. Tetrahedron 2012, 68, 3205-3209. [CrossRef]

61. Kim, H.; Lantvit, D.; Hwang, C.H.; Kroll, D.J.; Swanson, S.M.; Franzblau, S.G.; Orjala, J. Indole alkaloids from two cultured cyanobacteria, Westiellopsis sp. and Fischerella muscicola. Bioorg. Med. Chem. 2012, 20, 5290-5295. [CrossRef]

62. Smitka, T.A.; Bonjouklian, R.; Doolin, L.; Jones, N.D.; Deeter, J.B.; Yoshida, W.Y.; Patterson, G.M. Ambiguine isonitriles, fungicidal hapalindole-type alkaloids from three genera of blue-green algae belonging to the Stigonemataceae. J. Org. Chem. 1992, 57, 857-861. [CrossRef]

63. Huber, U.; Moore, R.E.; Patterson, G.M. Isolation of a nitrile-containing indole alkaloid from the terrestrial blue-green alga Hapalosiphon delicatulus. J. Nat. Prod. 1998, 61, 1304-1306. [CrossRef]

64. Raveh, A.; Carmeli, S. Antimicrobial ambiguines from the cyanobacterium Fischerella sp. collected in Israel. J. Nat. Prod. 2007, 70, 196-201. [CrossRef]

65. Mo, S.; Krunic, A.; Chlipala, G.; Orjala, J. Antimicrobial ambiguine isonitriles from the cyanobacterium Fischerella ambigua. J. Nat. Prod. 2009, 72, 894-899. [CrossRef]

66. Mo, S.; Krunic, A.; Santarsiero, B.D.; Franzblau, S.G.; Orjala, J. Hapalindole-related alkaloids from the cultured cyanobacterium Fischerella ambigua. Phytochem 2010, 71, 2116-2123. [CrossRef]

67. Hillwig, M.L.; Zhu, Q.; Liu, X. Biosynthesis of ambiguine indole alkaloids in cyanobacterium Fischerella ambigua. ACS Chem. Biol. 2014, 9, 372-377. [CrossRef]

68. Park, A.; Moore, R.E.; Patterson, G.M. Fischerindole L, a new isonitrile from the terrestrial blue-green alga Fischerella muscicola. Tetrahedron Lett. 1992, 33, 3257-3260. [CrossRef]

69. Etchegaray, A.; Rabello, E.; Dieckmann, R.; Moon, D.H.; Fiore, M.F.; Von Döhren, H.; Neilan, B.A. Algicide production by the filamentous cyanobacterium Fischerella sp. CENA 19. J. Appl. Phycol. 2004, 16, 237-243. [CrossRef] 
70. Asthana, R.K.; Srivastava, A.; Singh, A.P.; Singh, S.P.; Nath, G.; Srivastava, R.; Srivastava, B.S. Identification of an antimicrobial entity from the cyanobacterium Fischerella sp. isolated from bark of Azadirachta indica (Neem) tree. J. Appl. Phycol. 2006, 18, 33-39. [CrossRef]

71. Cagide, E.; Becher, P.G.; Louzao, M.C.; Espina, B.; Vieytes, M.R.; Juttner, F.; Botana, L.M. Hapalindoles from the cyanobacterium Fischerella: Potential sodium channel modulators. Chem. Res. Toxicol. 2014, 27, 1696-1706. [CrossRef] [PubMed]

72. Knoot, C.J.; Khatri, Y.; Hohlman, R.M.; Sherman, D.H.; Pakrasi, H.B. Engineered production of hapalindole alkaloids in the cyanobacterium Synechococcus sp. UTEX 2973. ACS Synth. Biol. 2019, 8, 1941-1951. [CrossRef]

73. Jimenez, J.I.; Huber, U.; Moore, R.E.; Patterson, G.M. Oxidized welwitindolinones from terrestrial Fischerella spp. J. Nat. Prod. 1999, 62, 569-572. [CrossRef] [PubMed]

74. Schwartz, R.E.; Hirsch, C.F.; Springer, J.P.; Pettibone, D.J.; Zink, D.L. Unusual cyclopropane-containing hapalindolinones from a cultured cyanobacterium. J. Org. Chem. 1987, 52, 3704-3706. [CrossRef]

75. Heck, K.; Alvarenga, D.O.; Shishido, T.K.; Varani, A.M.; Dörr, F.A.; Pinto, E.; Rouhiainen, L.; Jokela, J.; Sivonen, K.; Fiore, M.F. Biosynthesis of microcystin hepatotoxins in the cyanobacterial genus Fischerella. Toxicon 2018, 141, 43-50. [CrossRef]

76. Batsalova, T.; Basheva, D.; Bardarov, K.; Bardarov, V.; Dzhambazov, B.; Teneva, I. Assessment of the cytotoxicity, antioxidant activity and chemical composition of extracts from the cyanobacterium Fischerella major Gomont. Chemosphere 2019, $218,93-103$. [CrossRef] [PubMed] 